\title{
Erken Çocukluk Çalışmalarında Gündem Olan Konuların İncelenmesi: Yaşadıkça Eğitim Dergisinin 30 Yılı'
}

\author{
Evcan Afra DOMA* \\ Mehmet TORAN $^{* *}$
}

\begin{abstract}
Öz: Bu araştırmada, 1986-2015 yılları arasında ebeveynlere yönelik Türkiye'de yayımlanan Yaşadıkça Eğitim dergisinde erken çocuklukla ilgili makalelerin incelenmesi amaçlanmıştır. Nitel araştırma yöntemi ile yürütülen çalışmada 125 say1 içerisinde 231 makale dahil edilmiştir. Verilerin analizinde Makale Sınıflama Formu kullanılmıştır. Makalelerin derinlemesine incelenmesi için doküman incelemesi kullanılmıştır. Çalışmanın sonucunda, erken çocukluk döneminde çocuğun bütünsel gelişimi için anne baba eğitiminin önemli olduğu bulunmuştur. Tespit edilen diğer konulara daha az değinildiği belirlenmiştir. Değişen zamanla birlikte erken çocukluk döneminde öğretmenlerin de anne babalar kadar önemli olduğu anlaşılması üzerine Yaşadıkça Eğitim dergisinde buna göre yayın yapıldığı tespit edilmiştir. Yaşadıkça Eğitim dergisinde yayınlanan makalelerin tespit edilen her konu aralığında olması gerekliliği önerilmiştir.
\end{abstract}

Anahtar Sözcükler: Erken Çocukluk, Erken Çocukluk Çalışmaları, Yaşadıkça Eğitim Dergisi, Gündem

\section{Examining the Trending Issues in Early Childhood Studies: 30 Years of the Journal of Education for Life}

\begin{abstract}
This research analyses the articles focused on early childhood period in Journal of Education for Life, a journal for parents published between 1986 and 2015 in Turkey. The study which has been carried out with qualitative research method examines 231 articles from 125 issues. For the analysis of the data, the "Article Classification Form" has been used. For an in-depth analysis of the articles, document review is preferred as the research model. Findings show that the education of parents is critical for the holistic development of the child in early childhood period. It has been determined that other subjects have been addressed less comprehensively. With the changing times, it has been understood that the role of teachers is as critical as parents' and the publishing policy of Journal of Education for Life has adapted accordingly. It has been recommended that all the articles published in Journal of Education for Life to have a balanced distribution in all the subjects identified.
\end{abstract}

Keywords: Early Childhood, Early Childhood Studies, Journal of Education for Life, Trend

$1 \mathrm{Bu}$ araştırma birinci yazarın yüksek lisans tezinden türetilmiştir.

* İstanbul Okan Üniversitesi, Sosyal Bilimler Enstitüsü, Okul Öncesi Eğitimi Anabilim Dalı, İstanbul, Türkiye, e-posta: afradoma@gmail.com,

ORCID: https://orcid.org/0000-0001-6643-3579

**İstanbul Kültür Üniversitesi, Eğitim Fakültesi, Temel Eğitim Bölümü, İstanbul, Türkiye, e-posta: m.toran@iku.edu.tr, ORCID: https://orcid.org/0000-0003-3457-9113 
Erken çocukluk dönemi, bireyin dünyaya geldiği andan itibaren ilköğretim çağına kadar geçen 0-8 yaş arasındaki dönemi kapsayan, bireyin yaşamının ve gelişiminin temellerinin atıldığı en hassas ve en kritik yıllar olarak nitelendirilen dönem olarak kabul edilmektedir (Alıc1, 2018; Arat, 2008; Kerigan, 2018; Sönmez, 2019; Yıldız, 2017). Çocuğun gelişiminin büyük bir bölümü bu dönemde tamamlanmakta aynı zamanda bilişsel, dil, psikomotor, sosyal ve duygusal gelişiminin artmaya başlaması da yine bu dönemde ortaya çıkmaktadır (Kaya ve Efe, 2016). Çocuğun bilişinin gelişmeye başlaması ile akıl yürütme, öz düzenleme, mekânsal ilişkileri kavrayabilme, sıralama, kıyaslama ve karşılaştırma becerilerinde ilerlemeler görülür (Didin ve Köksal Akyol, 2018). Dil gelişimi ile çocuk ilişkilerini düzenleyebilme, duygu, düşünce ve eğilimlerini ifade edebilme yeterliliklerine erişir (Aksoy ve Baran, 2018). Sosyal ve duygusal gelişim ile çocuklarda iletişim, problem çözme, karar verme, kendini yönetme, olumlu sosyal ilişkiler başlatma ve devam ettirme, hoş olmayan durumlarla başa çıkma, çatışma çözme ve atılganlıkla ilgili becerilerin gelişimi görülür (Küçükturan ve Keleş, 2018). Motor gelişim, çocukların denge, esneklik, dikkat, kuvvet, eşgüdüm ve onları denetim altına alma becerilerinin gelişimini sağlar (Kaynak, 2016).

Erken çocukluk dönemi beyin gelişiminin ve sinaptik bağların en hızlı etkileşim içerisinde bulundukları dönemdir. Beyin gelişimi çocuğun bilişsel, dil, motor, sosyal ve duygusal gelişimi için sağlam bir alt yapı oluşturur. Bu nedenle yaşamın ilk yıllarını kapsayan erken çocukluk döneminde çocuklar çok hızlı büyür ve bu gelişim alanlarında hızla olgunlaşırlar. Beyin, bu dönemde hızla geliştiği için öğrenmede önemli bir faktör olan çevre gibi dış etmenlere çok fazla açık hale gelir (Milli Eğitim Bakanlığı [MEB], 2013).

Çevre, çocukların yaşamlarında fiziksel ve zihinsel gelişimlerini büyük oranda etkiler. Davranış ve doğal merak gibi sebeplerden dolayı çocuklar çevrenin etkilerine açık haldedirler. Bu nedenle çocukların sağlıklı olarak büyüyüp gelişebilmeleri için sağlıklı bir çevrede yaşamaları önem taşımaktadır (Çağlayan, 2015). Aile, çocuğun toplumsal uyumu ve gelişimini etkileyen önemli bir çevresel faktördür. Çocuğun yaşamının ilk yıllarında hayatta kalma ve temel ihtiyaçlarının karşılanmasında, çocuğun fiziksel, duygusal, bilişsel ve sosyal gelişiminin desteklenmesinde aile ve giderek genişleyen çevre oldukça önemlidir (Özgün, 2015). Dolayısıyla aile çocuğun kendine güven duymasını, kendine ve başka bireylere sevgi duymasını, kişilik gelişimini ve

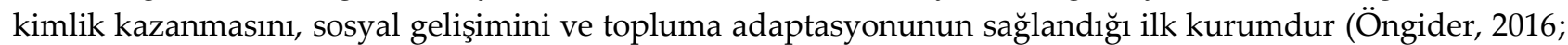
Özyürek, Çetin, Yıldırım, Evirgen ve Ergün, 2016). Çocuk, aile içerisinde temel öğrenme ile ilgili kazandığı deneyimleri erken çocukluk dönemi eğitim kurumlarında zenginleştirme ve pekiştirme fırsatı bulur (Cömert ve Güleç, 2004). Erken çocukluk dönemi eğitim kurumlarına devam eden çocukların uzun süre etkileşim içerisinde oldukları kişi öğretmenlerdir. Bu nedenle öğretmenlerin sabırlı, hoşgörülü, adil, dürüst, sevecen olmalarının yanı sıra kişisel özellikleri, düşünsel tutumları, duygusal tepkileri ve alışkanlıkları çocuklar üzerinde önemli etkiler bırakabilmektedir (Deniz ve Kesicioğlu, 2012; Yalçın, Yalçın ve Macun, 2017).

Gelişimsel perspektif ile birlikte tanımlanan çocukluk aynı zamanda sosyolojik ve tarihsel olarak da tanımlanmaya çalışılmıştır. Sosyolojik ve tarihsel bakış açısına göre çocukluk kavramı, yaşanılan toplumun sosyal değerlerine göre şekillenmektedir. Antik çă̆da çocukluk kavramı, sosyal değerler boyutunda incelendiğinde, çocuğun yedi yaşından öncesi hastalık, sonrası ise yetişkinlik olarak görülmekteydi. Yedi yaşına geldiğinde yetişkin olarak atfedilen çocuk ise işgücüne katılmaktaydı. Yine bu çağda çocuk eğitiminin yapı taşı aile olarak görülmekte ve çocuk eğitimi, çocuğu bakmakla yükümlü kişiler tarafından verilmekteydi (Koçyiğit, 2007; Toran, 2012). Çocukluğun tanımı ve eğitimi ile ilgili sistemli bilgiler ilk kez Eski Yunan'da eğitim düşüncesinin en öncelikli isimleri Platon ve Aristoteles tarafından tanımlanmıştır. 15. ve 16. yüzyıllar insanlık tarihinin geçiş dönemi olarak bilinmektedir. Bu dönemin düşünürleri Jan Amos Komensky, John Locke, Jean Jacques Rousseau tarafından çağdaş eğitimin temelleri atılmıştır (Toran, 2012). 15. yüzyılda Osmanlı Devleti'nde ise küçük çocukların eğitimi için Sıbyan Mektepleri açılmış fakat bu kuruluşlar oyundan ziyade ders üzerine odaklanmışlardır (Sıbyan Mektebi Tarihçesi, 2019). Erken çocukluk eğitiminin ortaya atılmasında ve erken çocukluk eğitiminin uygulanmaya başlamasında aynı zamanda kendilerinden sonraki düşünürlere de yol gösterici niteliğe sahip olan tüm bu düşünürlerin katkıları yadsınamayacak derecede fazladır. Tarihsel olarak erken çocukluk eğitimi ve uygulamaları Johann Heinrich Pestalozzi, Robert Owen, Friedrich Froebel, John Dewey ve Maria Montessori'yi etkileyerek teori ve uygulama geliştirmelerine yön vermiştir (Toran, 2012). Osmanlı Devleti de bu düşünürlerin teori ve uygulamalarından etkilenmiştir. Bunun 
üzerine 1847 yılında ilköğretimin ıslahı çalışmaları için "Etfalin Tedris ve Terbiyelerini Ne Vecihle Eylemeleri Lazım Geleceğine Dair Sıbyan Mekatibi Hâceleri Efendilerine İta Olunacak Talimat" adında bir rehber hazırlamıştır. Bu rehber, erken çocukluk dönemi eğitim çağındaki çocukları içine alan sıbyan mekteplerinin iyileştirilmesi için atılmış büyük bir adımdır (Bardak, 2010). 20. yüzyıl başlarında erken çocukluk eğitiminde Jean Piaget ve Lev Semenoviç Vygotsky çocuğun bilişsel gelişimine, Noam Chomsky dil gelişimine ve Gallahue motor gelişime odaklanmıştır (Çelik, 2018; Ulutaş, Demir ve Yayan, 2017). 20. yüzyılın başlarında Osmanlı Devleti'nde ise Ana Mektepler Nizamnamesi (15 Mart 1915) yayınlanmış ve bu sayede kentlerde anaokulları çoğalmıştır. Nizamnameden bir yıl sonra İstanbul'da 30'a yakın anaokulu açılmıştır (Çelik ve Gündoğdu, 2007). Günümüzde 2017-2018 verilerine göre ise Türkiye'de 24975 adet erken çocukluk dönemi eğitim kurumu bulunmaktadır (MEB, 2019).

Erken çocukluk dönemi eğitiminde görsel, işitsel ve kinestetik (dokunsal) öğrenme yöntemleri kullanılmakta ve bu öğrenme yöntemlerini kitap, dergi, televizyon vb. türdeki sosyal yayınlar beslemektedir. Kitap, dergi, televizyon gibi ürünler kişilerin öğrenme hızı ve yönünü olumlu ve olumsuz şekilde etkileyebilmektedir. Bu ürünlerin problemli kullanımı kişinin stres yaşamasına ve günlük etkinliklerinin bozulmasına sebebiyet verirken, sağlıklı kullanımı birçok alanda bilgilendirme yapabilmektedir (Demir, 2016). Bu bağlamda çocuğun öğrenme ve başarısı üzerinde büyük etkisi olan ailenin kitap, dergi, televizyon gibi sosyal ürünlerden etkilenme düzeyleri büyük önem arz etmektedir (Şimşek ve Şimşek, 2015).

Çocuğun gelişiminde kritik öneme sahip olan erken çocukluk dönemi aile, çevre ve okul bileşenleri çerçevesinde incelenmiştir. Erken çocukluk dönemi tarihsel gelişimi incelendiğinde, Antik çağdan itibaren eğitimin önem kazandığı görülmüş aynı zamanda erken çocukluk döneminin Türkiye'de ve dünyada farklı zamanlarda ve farklı şekillerde gelişim gösterdiği saptanmıştır. Dolayısıyla erken çocukluk eğitimini tarihsel bağlamda incelemek önemlidir. Bu bağlamda bu çalışmanın Türkiye'de erken çocukluk eğitiminin tarihini inceleyerek gündem olan konuların belirlenmesi adına alan yazına önemli bir katkı sağlayacağı varsayılmaktadır. Ayrıca erken çocukluk eğitiminde gündem olan konuların belirlenmesi, erken çocukluk eğitiminin hangi konulara önem verdiğini göstereceği düşünülmektedir. Bu gerekçeler doğrultusunda çalışmanın amacı, erken çocukluk döneminde gündem olan çalı̧̧maların incelenmesidir. Bu amaçla şu sorulara yanit aranmıştır:

1- Erken çocukluk döneminde gündem olan çalışmaların dağılımı nedir?

2- 10'ar yıllık değerlendirme yapıldığında gündem olan çalışmalar nelerdir?

3- Erken çocukluk döneminde gündem olan çalışmalar hangi pedagojik uygulamalara odaklanmıştır?

4- Erken çocukluk döneminde gündem olan çalışmalar hangi gelişim alanlarına odaklanmıştır?

5- Erken çocukluk döneminde gündem olan çalışmalar hangi önerileri geliştirmiştir?

\section{Yöntem}

\section{Araștırmanın Deseni}

Bu çalışma nitel araştırma deseni benimsenerek gerçekleştirilmiştir. Erken çocukluk döneminde gündem olmuş konuların incelenmesi ve yorumlanmasını amaçlayan bu araştırma için en uygun araştırma yönteminin nitel araştırma yöntemi olduğuna karar verilmiştir. Bu araştırmada 1986-2015 yılları arasında yayımlanmış popüler eğitim dergisi olan Yaşadıkça Eğitim dergisinin derinlemesine incelenmesi amaçlandığı için doküman incelemesi kullanılmıştır. Doküman incelemesi, araştııılması hedeflenen olgu veya olgular hakkında bilgi içeren yazılı materyallerin analizini kapsar (Yıldırım ve Şimşek, 2016). Araştırmanın yöntemini, geçmişten gelen olay veya olguların araştırılması ya da bir problemin geçmişle olan ilişkisinin incelenmesini sağlayan tarihsel metot (dokümanter tarih) oluşturmuştur. Tarihsel yöntem, geçmişteki olaylara dair gerçeği bulmak için geçmişin sorgulayıcı bir gözle incelenmesi ve değerlendirilmesidir (Kayhan, Bağcı ve Erişen, 2019).

\section{Araştırmanın Veri Kaynağı}

Araştırmanın veri kaynağını Yaşadıkça Eğitim dergisi oluşturmaktadır. Yaşadıkça Eğitim dergisi 1986'da 
yayımlanmaya başlamasıyla popüler eğitim dergisi olan ve 2015 yılı itibariyle akademik dergiye dönüşen Yaşadıkça Eğitim dergisinin 1986-2015 yılları arasında yayımlanan 125 sayının tamamı oluşturmaktadır. Yıllara göre derginin sayıları Tablo 1'de verilmiştir.

Tablo I

Yaşadıkça Ĕ̆itim Dergisinin Yıllara Göre Yayınlanan Sayılarının Dağılımı

\begin{tabular}{|c|c|c|c|c|c|c|}
\hline Yillar & 1.Say1 & 2.Sayı & 3.Sayı & 4.Sayı & 5.Sayı & 6.Say1 \\
\hline 1986 & $x$ & $x$ & & & & \\
\hline 1987 & $x$ & & & & & \\
\hline 1988 & $x$ & $x$ & $x$ & $x$ & $x$ & \\
\hline 1989 & $x$ & $x$ & $x$ & $x$ & & \\
\hline 1990 & $x$ & $x$ & $x$ & $x$ & & \\
\hline 1991 & $x$ & $x$ & $x$ & $x$ & $x$ & $x$ \\
\hline 1992 & $x$ & $x$ & $x$ & $x$ & $x$ & $X$ \\
\hline 1993 & $x$ & $x$ & $x$ & $x$ & $x$ & $x$ \\
\hline 1994 & $x$ & $x$ & $x$ & $x$ & $x$ & $x$ \\
\hline 1995 & $x$ & $x$ & $x$ & $x$ & $x$ & $x$ \\
\hline 1996 & $x$ & $x$ & $x$ & $x$ & $x$ & $x$ \\
\hline 1997 & $x$ & $x$ & $x$ & $x$ & $x$ & $x$ \\
\hline 1998 & $x$ & $x$ & $x$ & 4 ve 5.Sayılar & Birleştirilmiş & \\
\hline 1999 & $x$ & $x$ & $x$ & $x$ & & \\
\hline 2000 & $x$ & $x$ & $x$ & $x$ & & \\
\hline 2001 & $x$ & $x$ & $x$ & $x$ & & \\
\hline 2002 & $x$ & 2 ve 3.Sayılar & Birleştirilmiş & $x$ & & \\
\hline 2003 & $x$ & $x$ & $x$ & $x$ & & \\
\hline 2004 & $x$ & $x$ & 3 ve 4.Sayılar & Birleştirilmiş & & \\
\hline 2005 & $x$ & $x$ & $x$ & $x$ & & \\
\hline 2006 & $x$ & $x$ & $x$ & $x$ & & \\
\hline 2007 & $x$ & 2 ve 3.Sayılar & Birleştirilmiş & $X$ & & \\
\hline 2008 & $x$ & $x$ & $x$ & $x$ & & \\
\hline 2009 & $x$ & $x$ & $x$ & $x$ & & \\
\hline 2010 & $x$ & $x$ & $x$ & $x$ & & \\
\hline 2011 & $x$ & $x$ & $x$ & $x$ & & \\
\hline 2012 & $x$ & $x$ & $x$ & $x$ & & \\
\hline 2013 & $x$ & $x$ & $x$ & $x$ & & \\
\hline 2014 & $x$ & & & & & \\
\hline 2015 & $x$ & & & & & \\
\hline
\end{tabular}

Yaşadıkça Eğitim dergisi 1986-2015 yılları arasında popüler eğitim dergisi, 2015 yılı itibariyle akademik bir dergi olma özelliğine sahiptir. Bu araştırmada Yaşadıkça Eğitim dergisinin popüler eğitim dergisi olan sayıları incelenmiştir. Dolayısıyla araştırmanın veri kaynağını Yaşadıkça Eğitim dergisinin 1986-2015 yılları arasında yayımlanan 125 sayısı içinden "Erken Çocukluk Dönemi” ile ilgili konular oluşturmaktadır. Derginin tüm sayıları Yaşadıkça Eğitim dergisi arşivinden elde edilmiştir.

\section{Veri Toplama Araçları}

Makale sınıflama formu. Araştırma kapsamında yer alan her makale Makale Sınıflama Formu kullanılarak betimsel analizine tabi tutulmuştur. Makale Sınıflama Formu Sözbilir, Kutu ve Yaşar (2012) tarafından geliştirilmiş olup bu çalışmada revize edilerek kullanılmıştır. Revize edilen form, erken çocukluk eğitimi alanında uzman üç öğretim üyesi tarafından incelenerek formun kapsam geçerliği sağlanmıştır. Form, temel olarak dokuz bölümden oluşmaktadır: Makalenin künyesi, konusu, odaklandığı gelişim alanları, araştırma yöntemi, veri toplama araçları, örneklem, veri analiz yöntemleri, bulgular ve sonuçlar.

\section{Veri Toplama Süreci}

Veri toplama sürecinde Sözbilir ve diğerleri (2012) tarafından geliştirilen, araştırmacılar tarafından bu araştırma için revize edilen Makale Sınıflama Formu'nun kapsam geçerliliğini sağlayabilmek alanında uzman 
üç doktor öğretim üyesinin görüşleri alınmıştır. Uzman görüşleri doğrultusunda form yeniden düzenlenmiştir. Derginin rastgele seçilen üç sayısını araştırmacı form üzerinde kodlamıştır. Formun güvenirliliğini ölçmek için araştırmacının kodladığı dergiler başka bir araştırmacı tarafından farklı bir zamanda kodlanmıştır. Araştırmanın güvenirliği kodlayıcılar arası uyum yüzdesi (percent of agreement) indeksi kullanılarak belirlenmiştir. Kodlamanın kodlayıcılar arası uyumunu belirlemek için Miles ve Huberman (1994) tarafından önerilen Güvenirlik = Görüş birliği sayısı / (Toplam görüş birliği + Görüş ayrılığı sayısı) formülü kullanılmıştır. Bu formüle göre kodlayıcılar arasındaki uyum yüzdesi oranı 90 bulunmuştur. Kodlayıcılar arası uyumun $.80^{\prime}$ den yüksek olması nedeniyle araştırmada oluşturulan formun ve veri analizinin güvenirliği uygun bulunmuştur (Miles ve Huberman, 1994).

\section{Veri Analizi}

Araştırmada doküman incelemesi yöntemi kullanılarak ulaşılan dergilerin içerik ve betimsel analizi yapılmıştır. İçerik analizi bir veya birçok metnin içindeki sözcükler, kavramlar, deyim veya cümlelerin varlıklarını belirlemek ve anlamak, onları sayıya dökmek ve vaka ile ilgili bilgi edinilmesi için kullanılır (Seggie ve Bayburt, 2017). Betimsel analizde ise elde edilen veriler daha önceden belirlenen temalara göre özetlenir (Yıldırım ve Şimşek, 2016). Bu araştırmada da her bir makale Makale Sınıflama Formu kullanılarak incelenmiş ve ardından istatistik için kullanılan programa veri girişi yapılmıştır. Makale Sınıflama Formu'nun makalenin künyesi, konusu, odaklandığı gelişim alanları, araştırma yöntemi, veri toplama araçları, örneklem ve veri analiz teknikleri kısımları betimsel analiz ile incelenmiştir. Her bir makale formda yer alan ve önceden belirlenmiş kategorilere göre sınıflandırılmıştır.

\section{Bulgular}

1986-2015 yılları arasında popüler eğitim dergisi olarak Yaşadıkça Eğitim dergisinde erken çocukluk dönemine yönelik yayımlanan makalelerin konu olarak dağılımını incelemeyi amaçlayan "Erken çocukluk döneminde gündem olan çalışmaların dağılımı nedir?" alt amacına yönelik analiz sonuçları frekans ve yüzdeleri Tablo 2 ve Grafik 1'de verilmiştir.

\section{Tablo II}

Gündem Olan Konuların Dağılımı

\begin{tabular}{lcc}
\hline Gündem Olan Konular & f & $\%$ \\
\hline Anne Baba Eğitimi & 177 & $53,3 \%$ \\
\hline Öğretmen Eğitimi & 53 & $16,0 \%$ \\
\hline Yetişkin Eğitimi & 33 & $9,9 \%$ \\
\hline Yaratıcılık & 16 & $4,8 \%$ \\
\hline Sağlı & 16 & $4,8 \%$ \\
\hline Cinsel Eğitim & 10 & $3,1 \%$ \\
\hline Oyun & 8 & $2,4 \%$ \\
\hline Diğer* & 8 & $2,4 \%$ \\
\hline Teknoloji & 7 & $2,1 \%$ \\
\hline Fen Eğitimi & 4 & $1,2 \%$ \\
\hline Toplam & $332^{* *}$ & $100,0 \%$ \\
\hline * Birden fazla işaretleme & \\
**Hareket eğitimi, Sanat eğitimi, Eğitimle yetkili kişilere eğitim, Okulöncesi eğitimle ilgilenen kurum ve kuruluşlar için eğitim, Okulöncesi \\
eğitimde program eğitimi konularını içermektedir.
\end{tabular}




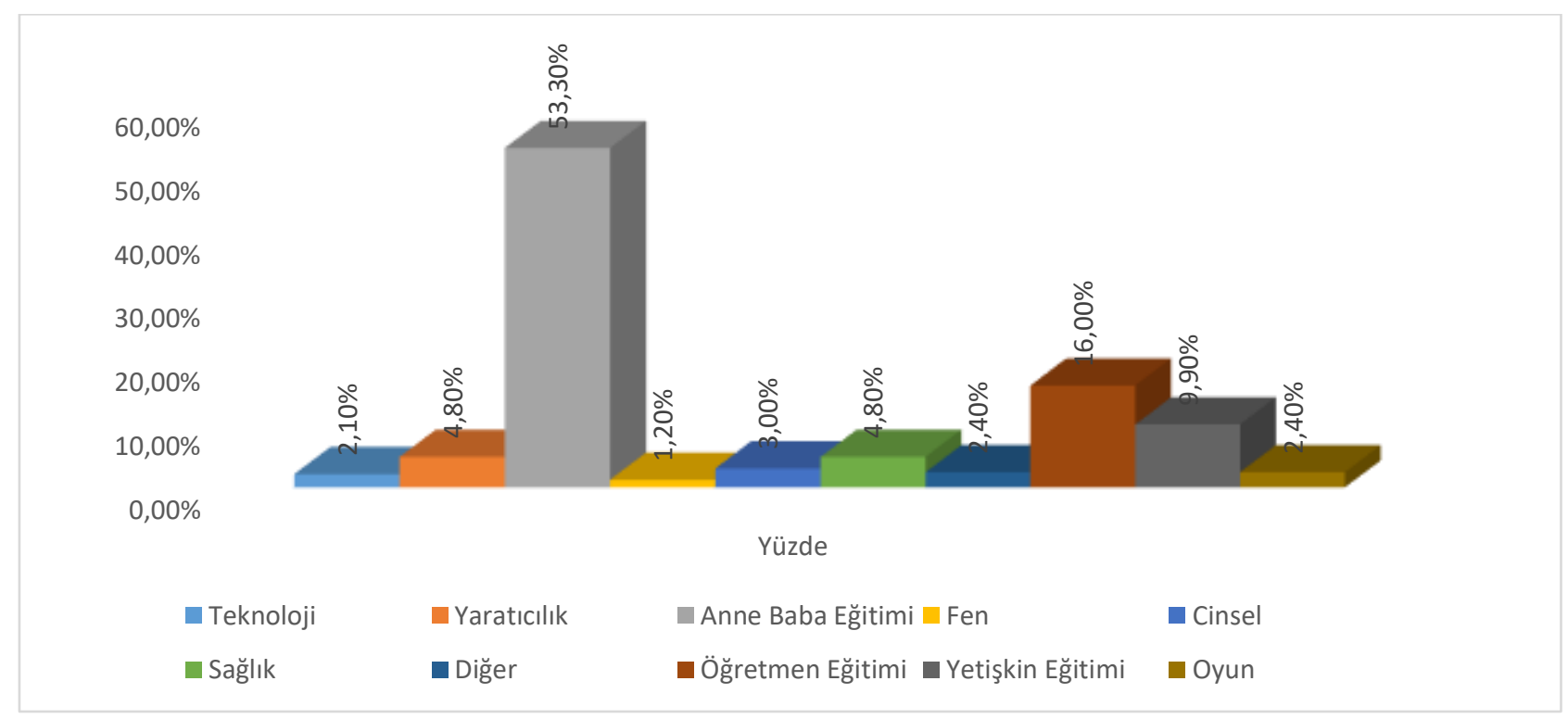

Grafik 1. Gündem olan konuların dağılımı

Tablo 2 ve Grafik 1'de 1986-2015 yılları arasında yayımlanan makalelerin kapsamı ve konuların dağılımı incelendiğinde, 177 (\%53,3) makalede en çok değinilen konunun anne baba eğitimi konusunun olduğu en az değinilen konunun ise $4(\% 1,2)$ makale ile fen eğitimi olduğu belirlenmiştir. Sırasıyla $53(\% 16)$ makalede öğretmen eğitimi, $33(\% 9,9)$ makalede yetişkin eğitimi, $16(\% 4,8)$ makalede yaratıcılık ve sağlık, $10(\% 3)$ makalede cinsel eğitim, $8(\% 2,4)$ makalede oyun ve diğer ve son olarak $7(\% 2,1)$ makalede teknolojiye yer verildiği görülmüştür.

1986-2015 yılları arasında popüler eğitim dergisi olarak Yaşadıkça Eğitim dergisinde erken çocukluk dönemine yönelik yayımlanan makalelerin 10 'ar yıllık periyotlar halinde incelemeyi amaçlayan " 10 'ar yıllık değerlendirme yapıldığında gündem olan çalışmalar nelerdir?" alt amacına yönelik analiz sonuçları frekans ve yüzde olarak Tablo 3 ve Grafik 2'de verilmiştir.

\section{Tablo III}

10'ar Yıllık Periyotta Gündem Olan Çalışmaların Dă̆ılımı

\begin{tabular}{|c|c|c|c|c|}
\hline \multirow{2}{*}{ Gündem Olan Konular } & & \multicolumn{3}{|c|}{ Yillar } \\
\hline & & 1986-1995 & 1996-2005 & 2006-2015 \\
\hline \multirow{2}{*}{ Teknoloji } & $\mathrm{f}$ & 4 & 1 & 2 \\
\hline & $\%$ & $2,45 \%$ & $0,91 \%$ & $3,3 \%$ \\
\hline \multirow{2}{*}{ Yaratıcılık } & $\mathrm{f}$ & 6 & 6 & 4 \\
\hline & $\%$ & $3,68 \%$ & $5,5 \%$ & $6,66 \%$ \\
\hline \multirow{2}{*}{ Anne-Baba Eğitimi } & $\mathrm{f}$ & 111 & 47 & 19 \\
\hline & $\%$ & $68,09 \%$ & $43,11 \%$ & $31,66 \%$ \\
\hline \multirow{2}{*}{ Fen Eğitimi } & $\mathrm{f}$ & 1 & 3 & 0 \\
\hline & $\%$ & $0,61 \%$ & $2,75 \%$ & $0,0 \%$ \\
\hline \multirow[b]{2}{*}{ Cinsel Eğitim } & $\mathrm{f}$ & 5 & 4 & 1 \\
\hline & $\%$ & 3,06 & $3,66 \%$ & $1,66 \%$ \\
\hline \multirow{2}{*}{ Sağlik } & $\mathrm{f}$ & 13 & 3 & 0 \\
\hline & $\%$ & $7,97 \%$ & $2,75 \%$ & $0,0 \%$ \\
\hline \multirow{2}{*}{ Oyun } & $\mathrm{f}$ & 6 & 0 & 2 \\
\hline & $\%$ & 3,68 & $0,0 \%$ & $3,3 \%$ \\
\hline \multirow{2}{*}{ Öğretmen Eğitimi } & $\mathrm{f}$ & 13 & 24 & 16 \\
\hline & $\%$ & $7,97 \%$ & $22,01 \%$ & $26,6 \%$ \\
\hline \multirow{2}{*}{ Yetişkin Eğitimi } & $\mathrm{f}$ & 1 & 19 & 13 \\
\hline & $\%$ & $0,61 \%$ & $17,43 \%$ & $21,66 \%$ \\
\hline \multirow{2}{*}{ Diğer } & $\mathrm{f}$ & 3 & 2 & 3 \\
\hline & $\%$ & $1,84 \%$ & $1,83 \%$ & $5 \%$ \\
\hline Toplam & $\mathrm{f}$ & 163 & 109 & 60 \\
\hline
\end{tabular}




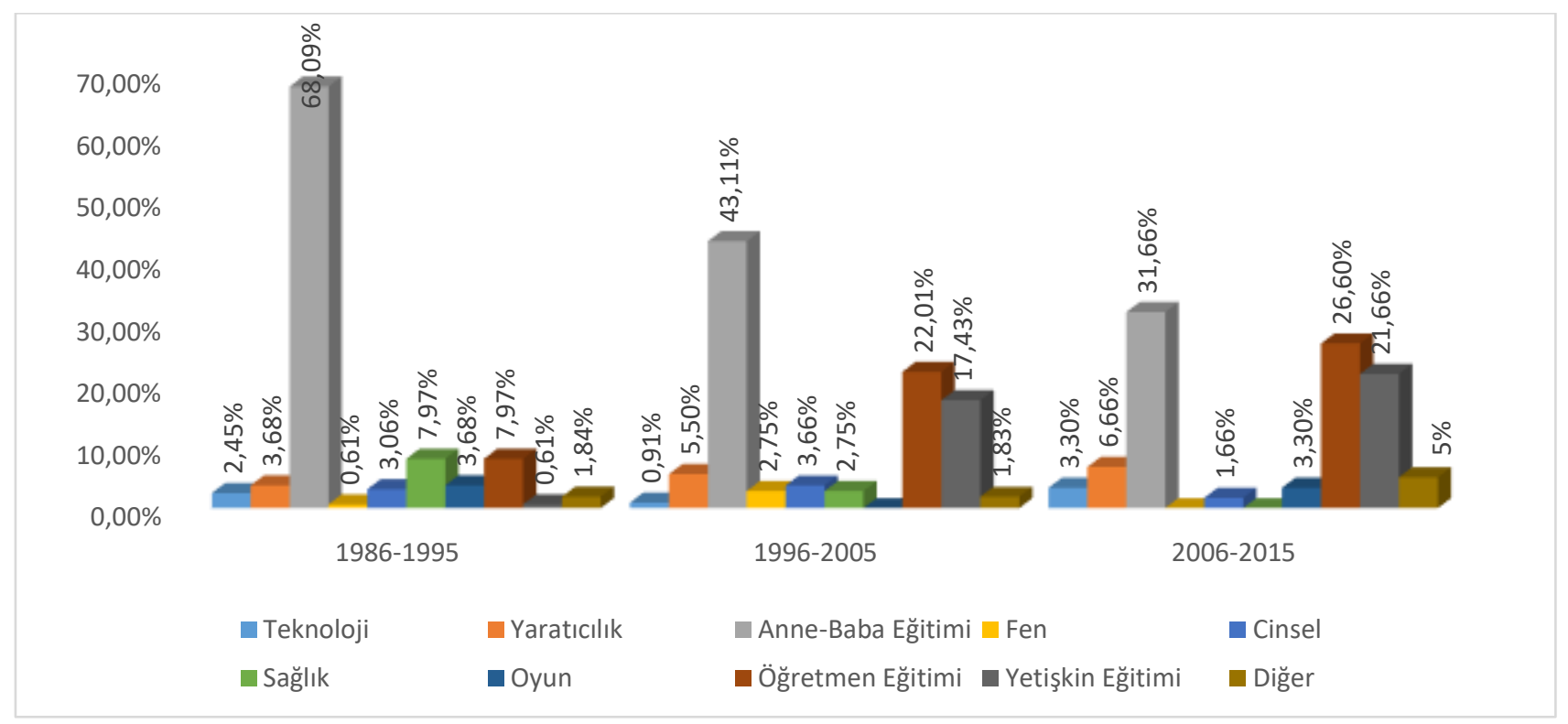

Grafik 2. 10'ar yıllık periyotta gündem olan konuların dağılımı

Tablo 3 ve Grafik 2'de 1986-1995 yılları arasında yayımlanan makalelerin kapsamı ve konuların dağılımı incelendiğinde, 111 (\%68) makalede en çok değinilen konunun anne baba eğitimi konusunun, en az değinilen konunun ise $1(\% 0,6)$ ile fen eğitimi ve yetişkin eğitimi olduğu belirlenmiştir. Sırasıyla $13(\% 7,9)$ makalede sağlık ve öğretmen eğitimi, $6(\% 3,6)$ makalede yaratıcılık ve oyun eğitimi, 5 (\%3) makalede cinsel eğitim, 4 $(\% 2,4)$ makalede teknoloji ve $3(\% 1,8)$ makalede diğer konulara yer verildiği görülmüştür.

1996-2005 yılları arasında yayımlanan makalelerin kapsamı ve konuların dağılımı incelendiğinde, 47 $(\% 43,1)$ makalede en çok değinilen konunun anne baba eğitimi olduğu, en az değinilen konunun ise $1(\% 0,9)$ ile teknoloji olduğu belirlenmiştir. Sırasıyla 24 (\%22) makalede öğretmen eğitimi, $19(\% 17,4)$ makalede yetişkin eğitimi, $6(\% 5,5)$ makalede yaratıclık, $4(\% 3,6)$ makalede cinsel eğitim, $3(\% 2,7)$ makalede fen eğitimi ve 2 $(\% 1,8)$ makalede diğer konulara yer verildiği görülmüştür. 1996-2005 yılları arasında yayınlanan makalelerin kapsamı ve konuları incelendiğinde oyun eğitimine yer verilmediği saptanmıştır.

2006-2015 yılları arasında yayımlanan makalelerin kapsamı ve konuların dağılımı incelendiğinde, 19 $(\% 31,6)$ makalede en çok değinilen konunun anne baba eğitimi konusunun olduğu, en az değinilen konunun ise $1(\% 1,6)$ ile cinsel eğitim olduğu belirlenmiştir. Sırasıyla $16(\% 26,6)$ makalede öğretmen eğitimi, $13(\% 21,6)$ makalede yetişkin eğitimi, $4(\% 6,6)$ makalede yaratıcılık, $3(\% 5)$ makalede diğer ve $2(\% 3,3)$ makalede oyun eğitimi konularına yer verildiği görülmüştür. 2006-2015 yılları arasında yayımlanan makalelerin kapsamı ve konuları incelendiğinde fen ve sağlık eğitimi konularına yer vermediği saptanmıştır.

1986-2015 yılları arasında popüler eğitim dergisi olarak Yaşadıkça Eğitim dergisinde erken çocukluk dönemine yönelik yayımlanan makalelerin odaklanılan pedagojik uygulamalar bağlamında incelemeyi amaçlayan "Erken çocukluk döneminde gündem olan çalışmalar hangi pedagojik uygulamalara odaklanmıştır?" alt amacına yönelik analiz sonuçları frekans ve yüzde olarak Tablo 4 ve Grafik 3'te verilmiştir.

Tablo IV

Odaklanılan Pedagojik Uygulama ile Gündem Olan Konuların Dă̆ılımı

\begin{tabular}{lccc}
\hline \multirow{2}{*}{ Gündem Olan Konular } & & \multicolumn{2}{c}{ Odaklanılan Pedagojik Uygulamalar } \\
\cline { 2 - 4 } & & Çocuk temelli & Program temelli \\
\cline { 2 - 4 } Teknoloji & $\mathrm{f}$ & 7 & 0 \\
\hline \multirow{2}{*}{ Yaratıcılık } & $\mathrm{f}$ & $2,15 \%$ & $0,0 \%$ \\
\hline \multirow{2}{*}{ Anne-Baba Eğitimi } & $\%$ & 16 & $0,0 \%$ \\
\hline \multirow{nyyy}{*}{ Fen Eğitimi } & $\mathrm{f}$ & $4,92 \%$ & 1 \\
\cline { 2 - 4 } & $\mathrm{f}$ & $54,15 \%$ & 0 \\
\hline
\end{tabular}




\begin{tabular}{|c|c|c|c|}
\hline & & & \multirow{2}{*}{$0,0 \%$} \\
\hline & $\%$ & $1,23 \%$ & \\
\hline \multirow{2}{*}{ Cinsel Eğitim } & $\mathrm{f}$ & 10 & 0 \\
\hline & $\%$ & 3,07 & $0,0 \%$ \\
\hline \multirow{2}{*}{ Sağlık } & $\mathrm{f}$ & 16 & 0 \\
\hline & $\%$ & $4,92 \%$ & $0,0 \%$ \\
\hline \multirow{2}{*}{ Oyun } & $\mathrm{f}$ & 8 & 0 \\
\hline & $\%$ & 2,46 & $0,0 \%$ \\
\hline \multirow{2}{*}{ Öğretmen Eğitimi } & $\mathrm{f}$ & 52 & 1 \\
\hline & $\%$ & $16 \%$ & $14,28 \%$ \\
\hline \multirow{2}{*}{ Yetişkin Eğitimi } & $\mathrm{f}$ & 30 & 3 \\
\hline & $\%$ & $9,23 \%$ & $42,85 \%$ \\
\hline \multirow{2}{*}{ Diğer } & $\mathrm{f}$ & 6 & 2 \\
\hline & $\%$ & $1,84 \%$ & $28,57 \%$ \\
\hline Toplam & $\mathrm{f}$ & 325 & 7 \\
\hline
\end{tabular}

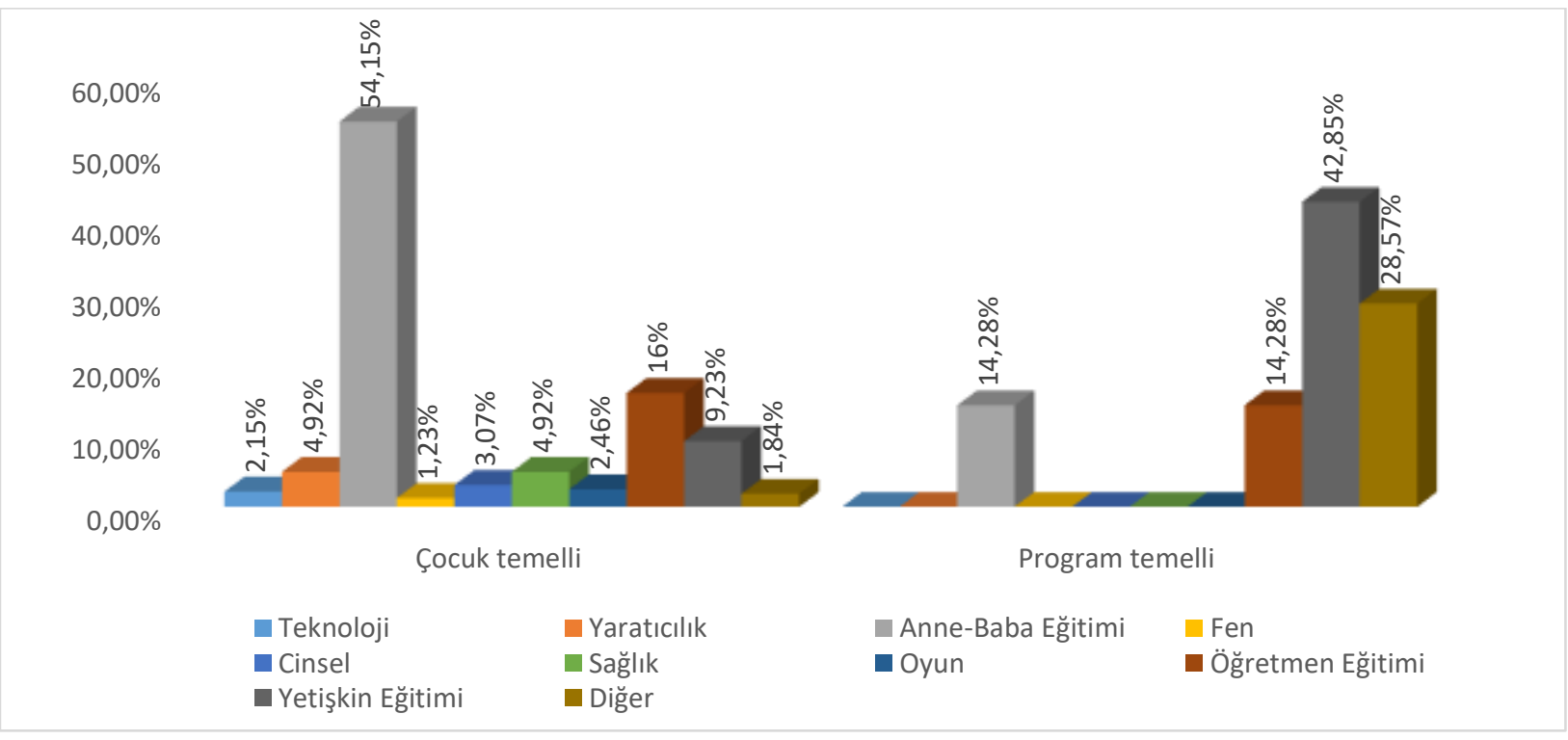

Grafik 3. Odaklanılan pedagojik uygulama ile gündem olan konuların dağılımı

Tablo 4 ve Grafik 3'te 1986-2015 yılları arasında yayımlanan makalelerin kapsamı ve konuların dağılımı incelendiğinde, $325(\% 97,8)$ makalede çocuk temelli ve $7(\% 2,2)$ makalede program temelli uygulama olduğu belirlenmiştir.

1986-2015 yılları arasında popüler eğitim dergisi olarak Yaşadıkça Eğitim dergisinde erken çocukluk dönemine yönelik yayımlanan makalelerin odaklandığı çocuk temelli pedagojik uygulamalar incelendiğinde, $176(\% 54,1)$ makalede en çok değinilen konunun anne baba eğitimi konusu olduğu, en az değinilen konunun ise $4(\% 1,2)$ makalede fen eğitimi olduğu belirlenmiştir. Sırasıyla $52(\% 16)$ makalede öğretmen eğitimi, 30 $(\% 9,2)$ makalede yetişkin eğitimi, $16(\% 4,9)$ makalede yaratıcllı ve sağlık eğitimi, $10(\% 3)$ makalede cinsel eğitim, $8(\% 2,4)$ makalede oyun, $7(\% 2,1)$ makalede teknoloji eğitimi ve $6(\% 1,8)$ makalede diğer konulara yer verdiği görülmüştür.

1986-2015 yılları arasında popüler eğitim dergisi olarak Yaşadıkça Eğitim dergisinde erken çocukluk dönemine yönelik yayımlanan makalelerin odaklandığı program temelli pedagojik uygulamalar incelendiğinde, $3(\% 42,8)$ makalede en çok değinilen konunun yetişkin eğitimi konusu olduğu ve en az değinilen konunun ise $1(\% 14,2)$ makalede anne baba ve öğretmen eğitimi olduğu belirlenmiştir. En fazla değinilen ikinci konu $2(\% 28,5)$ makalede diğer konusu olduğu görülmüştür. Yaşadıkça Eğitim dergisinde erken çocukluk dönemine yönelik yayımlanan makalelerin odaklandığı çocuk temelli pedagojik uygulamalar incelendiğinde teknoloji, yaratıcılık, fen, cinsel, sağlık ve oyun eğitimi konularına değinilmediği görülmüştür.

1986-2015 yılları arasında popüler eğitim dergisi olarak Yaşadıkça Eğitim dergisinde erken çocukluk dönemine yönelik yayımlanan makalelerin odaklanılan gelişim alanı bağlamında incelemeyi amaçlayan 
"Erken çocukluk döneminde gündem olan çalışmalar hangi gelişim alanlarına odaklanmıştır?" alt amacına yönelik analiz sonuçları frekans ve yüzdeleri Tablo 5 ve Grafik 4'te verilmiştir.

Tablo V

Odaklanılan Gelişim Alanı ile Gündem Olan Çalışmaların Dağılımı

\begin{tabular}{|c|c|c|c|c|c|c|c|c|c|c|c|c|}
\hline \multirow{2}{*}{$\begin{array}{l}\text { Odaklanılan } \\
\text { Gelişim } \\
\text { Alanları ve } \\
\text { Beceriler }\end{array}$} & \multicolumn{12}{|c|}{ Konular } \\
\hline & & Teknoloji & i Yaratıcılık & $\begin{array}{l}\text { Anne Baba } \\
\text { Eğitimi }\end{array}$ & $\begin{array}{c}\text { Fen } \\
\text { Eğitimi }\end{array}$ & $\begin{array}{l}\text { Cinsel } \\
\text { Eğitim }\end{array}$ & Diğer & Sağlık & Oyun & $\begin{array}{c}\text { Öğretmen } \\
\text { Eğitimi }\end{array}$ & $\begin{array}{l}\text { Yetişkin } \\
\text { Eğitimi }\end{array}$ & Toplam \\
\hline \multirow{2}{*}{ Bilişsel } & $\mathrm{f}$ & 5 & 15 & 75 & 4 & 4 & 7 & 5 & 30 & 12 & 6 & \multirow{2}{*}{$\begin{array}{c}163 \\
(\% 28,9)\end{array}$} \\
\hline & $\%$ & 3,1 & 9,2 & 46,0 & 2,4 & 2,4 & 4,3 & 3,1 & 18,4 & 7,4 & 3,7 & \\
\hline \multirow{2}{*}{ Psikomotor } & $\mathrm{f}$ & 0 & 3 & 30 & 0 & 1 & 6 & 3 & 11 & 6 & 6 & \multirow{2}{*}{$\begin{array}{c}66 \\
(\% 11,7)\end{array}$} \\
\hline & $\%$ & 0,0 & 4,5 & 45,5 & 0,0 & 1,5 & 9,1 & 4,5 & 16,7 & 9,1 & 9,1 & \\
\hline \multirow{2}{*}{ Dil } & $\mathrm{f}$ & 3 & 0 & 39 & 0 & 1 & 3 & 1 & 12 & 9 & 2 & \multirow{2}{*}{$\begin{array}{c}70 \\
(\% 12,4)\end{array}$} \\
\hline & $\%$ & 4,3 & 0,0 & 55,7 & 0,0 & 1,4 & 4,3 & 1,4 & 17,1 & 12,9 & 2,9 & \\
\hline Sosyal ve & $\underline{f}$ & 2 & 6 & 116 & 0 & 6 & 2 & 8 & 35 & 20 & 7 & \multirow{2}{*}{$\begin{array}{c}202 \\
(\% 35,8)\end{array}$} \\
\hline Duygusal & $\%$ & 1,0 & 3,0 & 57,4 & 0,0 & 3,0 & 1,0 & 4,0 & 17,2 & 9,9 & 3,5 & \\
\hline Özbakım & $\mathrm{f}$ & 0 & 0 & 40 & 0 & 5 & 8 & 0 & 5 & 3 & 2 & \multirow{2}{*}{$\begin{array}{c}63 \\
(\% 11,2) \\
\end{array}$} \\
\hline Becerileri & $\%$ & 0,0 & 0,0 & 63,5 & 0,0 & 7,9 & 12,7 & 0,0 & 7,9 & 4,8 & 3,2 & \\
\hline Toplam & $\mathrm{f}$ & 10 & 24 & 300 & 4 & 17 & 26 & 17 & 93 & 50 & 23 & $\begin{array}{c}564^{*} \\
(\% 100)\end{array}$ \\
\hline
\end{tabular}

* Birden fazla işaretleme

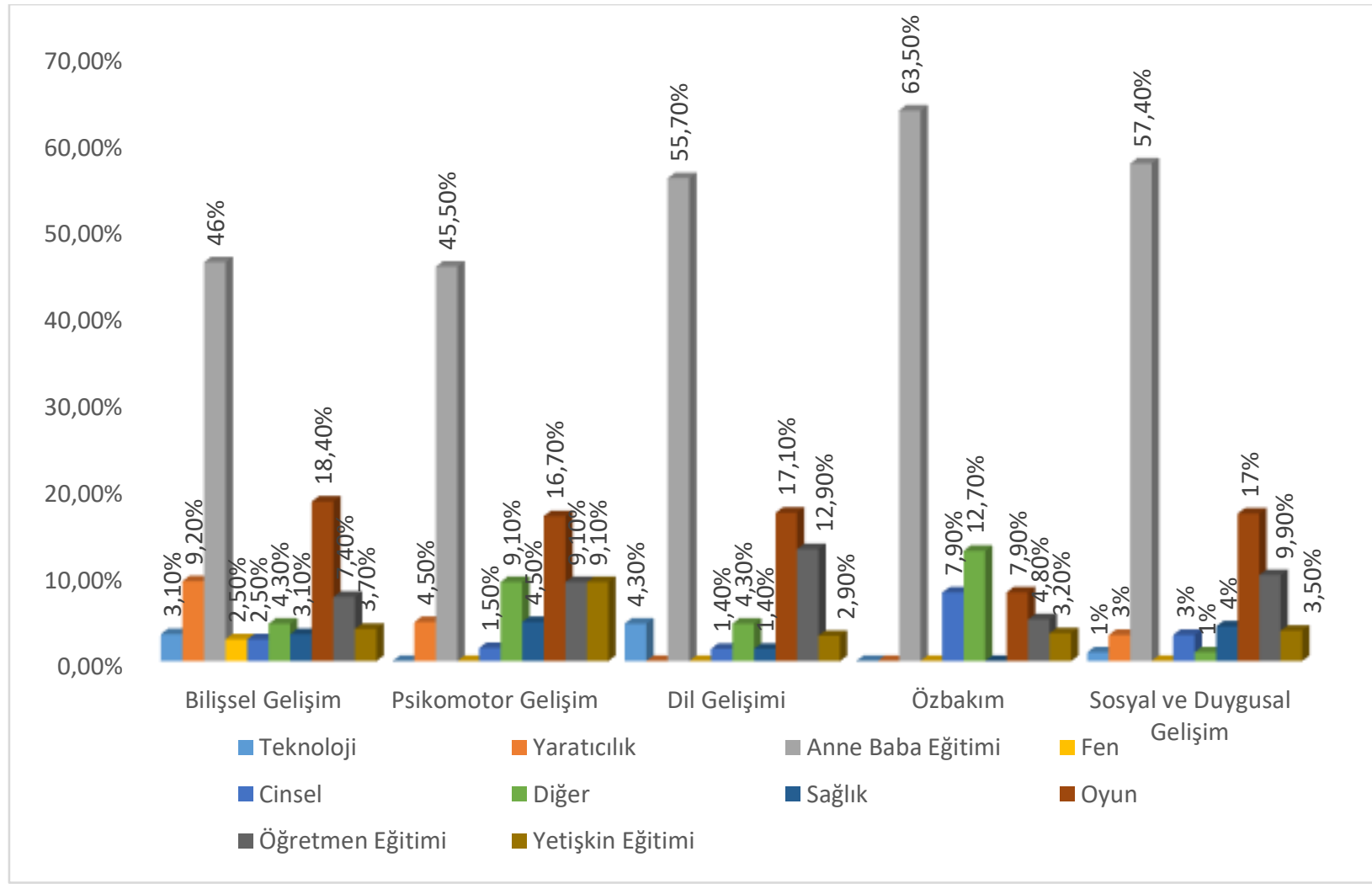

Grafik 4. Odaklanılan gelişim alanı ile gündem olan konuların dağılımı

1986-2015 yılları arasında yayımlanan makalelerin kapsamı ve konuların dağılımı incelendiğinde, 202 $(\% 35,8)$ makalede sosyal ve duygusal gelişim en çok değinilen gelişim alanı olarak belirlenmiştir. Sosyal ve duygusal gelişim alanında konu dağılımı incelendiğinde, $116(\% 57,4)$ makalede en çok değinilen konunun anne baba eğitimi konusunun olduğu ve en az değinilen konunun ise 2 (\%1) makalede diğer ve teknoloji olduğu belirlenmiştir. Sırasıyla 35 (\%17) makalede oyun, 20 (\%9,9) makalede öğretmen eğitimi, 8 (\%4) makalede sağlık, $7(\% 3,5)$ makalede yetişkin eğitimi ve $6(\% 3)$ makalede cinsel ve yaratıcılık eğitimi konularına yer verildiği görülmüştür. Yaşadıkça Eğitim dergisinde erken çocukluk dönemine yönelik yayımlanan 
makalelerin sosyal ve duygusal gelişime odaklanan makalelerde fen eğitimi konusuna değinilmediği görülmüştür.

1986-2015 yılları arasında yayımlanan makalelerin kapsamı ve konuların dağılımı incelendiğinde, 163 $(\% 28,9)$ makalede bilişsel gelişim en çok değinilen ikinci gelişim alanı olarak belirlenmiştir. Bilişsel gelişim alanının konu dağılımı incelendiğinde, 75 (\%46) makalede en çok değinilen konunun anne baba eğitimi konusunun olduğu ve en az değinilen konunun ise $4(\% 2,5)$ makalede fen ve cinsel eğitim olduğu belirlenmiştir. Sırasıyla 30 (\%18,4) makalede oyun, $15(\% 9,2)$ makalede yaratıcılık eğitimi, $12(\% 7,4)$ makalede öğretmen eğitimi, $7(\% 4,3)$ makalede diğer, $6(\% 3,7)$ makalede yetişkin eğitimi ve $5(\% 3,1)$ makalede sağlik ve teknoloji eğitimi konularına yer verildiği görülmüştür.

1986-2015 yılları arasında yayımlanan makalelerin kapsamı ve konuların dağılımı incelendiğinde, 70 $(\% 12,4)$ makalede dil gelişim en çok değinilen üçüncü gelişim alanı olarak belirlenmiştir. Dil gelişim alanının konu dağılımı incelendiğinde, 39 (\%55,7) makalede en çok değinilen konunun anne baba eğitimi konusunun olduğu ve en az değinilen konunun ise $1(\% 1,4)$ makalede sağlık ve cinsel eğitim olduğu belirlenmiştir. Sirasıyla $12(\% 17,1)$ makalede oyun, $9(\% 12,9)$ makalede öğretmen eğitimi ve $3(\% 4,3)$ makalede diğer ve teknoloji eğitimi konularına yer verildiği görülmüştür. Yaşadıkça Eğitim dergisinde erken çocukluk dönemine yönelik yayımlanan makalelerin dil gelişimine odaklanan makalelerde fen ve yaratıcılık eğitimi konularına değinilmediği görülmüştür.

1986-2015 yılları arasında yayımlanan makalelerin kapsamı ve konuların dağılımı incelendiğinde, 66 $(\% 11,7)$ makalede psikomotor gelişim en çok değinilen dördüncü gelişim alanı olarak belirlenmiştir. Psikomotor gelişim alanının konu dağılımı incelendiğinde, 30 (\%45,5) makalede en çok değinilen konunun anne baba eğitimi konusunun olduğu ve en az değinilen konunun ise $3(\% 4,5)$ makalede yaratıcılık ve sağlık eğitimi olduğu belirlenmiştir. Sırasıyla $11(\% 16,7)$ makalede oyun ve $6(\% 9,1)$ makalede diğer, öğretmen ve yetişkin eğitimi konularına yer verildiği görülmüştür. Yaşadıkça Eğitim dergisinde erken çocukluk dönemine yönelik yayımlanan makalelerin psikomotor gelişime odaklanan makalelerde fen ve teknoloji eğitimi konularına değinilmediği görülmüştür.

1986-2015 yılları arasında yayımlanan makalelerin kapsamı ve konuların dağılımı incelendiğinde, 63 $(\% 11,1)$ makalede özbakım en az değinilen beşinci gelişim alanı olarak belirlenmiştir. Özbakımın konu dağılımı incelendiğinde, 40 (\%63,5) makalede en çok değinilen konunun anne baba eğitimi konusunun olduğu ve en az değinilen konunun ise $2(\% 3,2)$ makalede yetişkin eğitimi olduğu belirlenmiştir. Sırasıyla $8(\% 12,7)$ makalede diğer, $5(\% 7,9)$ makalede oyun ve cinsel eğitim ve $3(\% 4,8)$ makalede öğretmen eğitimi konularına yer verildiği görülmüştür. Yaşadıkça Eğitim dergisinde erken çocukluk dönemine yönelik yayımlanan makalelerin özbakıma odaklanan makalelerde fen, sağlık, yaratıcıllk ve teknoloji eğitimi konularına değinilmediği görülmüştür.

1986-2015 yılları arasında popüler eğitim dergisi olarak Yaşadıkça Eğitim dergisinde erken çocukluk dönemine yönelik yayımlanan makalelerin geliştirilen öneri bağlamında incelemeyi amaçlayan "Erken çocukluk döneminde gündem olan çalışmalar hangi önerileri geliştirmiştir?" alt amacına yönelik analiz sonuçları frekans ve yüzde olarak Tablo 6 ve Grafik 5'te verilmiştir. 
Tablo VI

Evcan Afra DOMA \& Mehmet TORAN

Geliştirilen Öneri ile Gündem Olan Çalışmaların Dağıllımı

\begin{tabular}{|c|c|c|c|c|c|c|c|c|c|c|c|c|}
\hline \multirow[b]{2}{*}{ Geliştirilen Öneriler } & \multicolumn{12}{|c|}{ Gündem Olan Konular } \\
\hline & & Teknoloji & Yaratıcılık & Anne Baba Eğitimi & Fen Eğitimi & Cinsel Eğitim & Sağlık & Oyun & Yetişkin Eğitimi & Öğretmen Eğitimi & Diğer & Toplam \\
\hline \multirow{2}{*}{ Anne Baba } & $\mathrm{f}$ & 6 & 14 & 174 & 1 & 9 & 6 & 34 & 3 & 14 & 15 & \multirow{2}{*}{$276(\% 56,6)$} \\
\hline & $\%$ & 2,2 & 5,1 & 63,0 & 0,4 & 3,3 & 2,2 & 12,3 & 1,0 & 5,1 & 5,4 & \\
\hline \multirow{2}{*}{ Öğretmen } & $\mathrm{f}$ & 1 & 9 & 41 & 3 & 2 & 3 & 53 & 5 & 15 & 2 & \multirow{2}{*}{$134(\% 27,4)$} \\
\hline & $\%$ & 7 & 6,7 & 30,6 & 2,2 & 1,5 & 2,2 & 39,6 & 3,7 & 11,2 & 1,5 & \\
\hline \multirow{2}{*}{ Araştırmacı } & $\mathrm{f}$ & 0 & 0 & 2 & 0 & 0 & 0 & 3 & 0 & 1 & 0 & \multirow{2}{*}{$6(\% 1,2)$} \\
\hline & $\%$ & 0,0 & 0,0 & 33,3 & 0,0 & 0,0 & 0,0 & 50,0 & 0,0 & 16,7 & 0,0 & \\
\hline \multirow{2}{*}{$\begin{array}{l}\text { Çocukla çalışan diğer } \\
\text { profesyoneller }\end{array}$} & $\mathrm{f}$ & 1 & 0 & 7 & 0 & 2 & 0 & 5 & 1 & 9 & 1 & \multirow{2}{*}{$26(\% 5,4)$} \\
\hline & $\%$ & 3,8 & 0,0 & 26,9 & 0,0 & 7,8 & 0,0 & 19,3 & 3,8 & 34,6 & 3,8 & \\
\hline \multirow{2}{*}{$\begin{array}{l}\text { Politika Geliştirici ve } \\
\text { Yasa Koyucular }\end{array}$} & $\mathrm{f}$ & 0 & 2 & 3 & 0 & 0 & 0 & 3 & 4 & 8 & 1 & \multirow{2}{*}{$21(\% 4,3)$} \\
\hline & $\%$ & 0,0 & 9,5 & 14,3 & 0,0 & 0,0 & 0,0 & 14,3 & 19,0 & 38,1 & 4,8 & \\
\hline \multirow{2}{*}{ Çocuk Çevresi } & $\mathrm{f}$ & 0 & 0 & 5 & 0 & 1 & 0 & 0 & 0 & 6 & 0 & \multirow{2}{*}{$12(\% 2,4)$} \\
\hline & $\%$ & 0,0 & 0,0 & 41,7 & 0,0 & 8,3 & 0,0 & 0,0 & 0,0 & 50,0 & 0,0 & \\
\hline \multirow{2}{*}{ Medya } & $\mathrm{f}$ & 2 & 0 & 4 & 0 & 1 & 0 & 2 & 0 & 4 & 0 & \multirow{2}{*}{$13(\% 2,7)$} \\
\hline & $\%$ & 15,4 & 0,0 & 30,8 & 0,0 & 7,7 & 0,0 & 15,4 & 0,0 & 30,8 & 0,0 & \\
\hline Toplam & $\mathrm{f}$ & 10 & 25 & 236 & 4 & 15 & 9 & 100 & 13 & 57 & 19 & $488^{*}(\% 100)$ \\
\hline
\end{tabular}

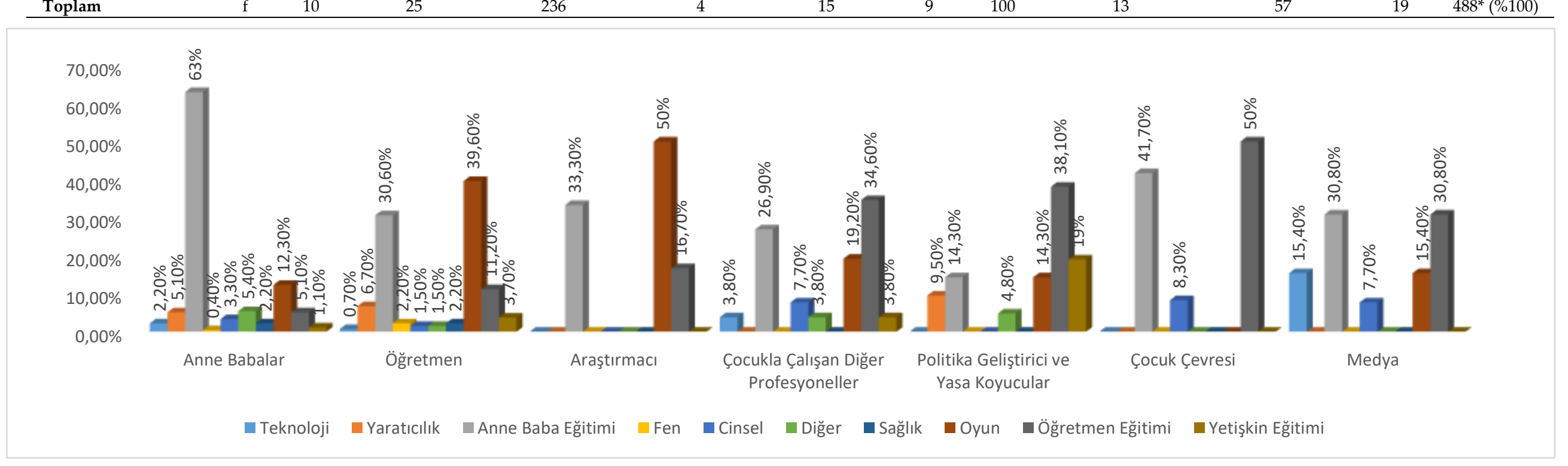

Grafik 5: Geliştirilen öneri ile gündem olan konuların dağılımı 
1986-2015 yılları arasında yayımlanan makalelerin kapsamı ve konuların dağılımı incelendiğinde, 276 $(\% 56,5)$ makalede en çok önerinin anne babalar için geliştirildiği belirlenmiştir. Anne babalar için geliştirilen önerilerin konu dağılımları incelendiğinde, 174 (\%63) makalede en çok değinilen konunun anne baba eğitimi konusunun olduğu ve en az değinilen konunun ise $1(\% 0,4)$ makalede fen eğitimi olduğu belirlenmiştir. Sırasıyla $34(\% 12,3)$ makalede oyun eğitimi, 15 (\%5,4) makalede diğer, $14(\% 5,1)$ makalede yaratıcllık ve öğretmen eğitimi, $9(\% 3,3)$ makalede cinsel eğitim, $6(\% 2,2)$ makalede sağlık ve teknoloji eğitimi ve 3 makalede $(\% 1,1)$ yetişkin eğitimi konularına yer verildiği görülmüştür.

1986-2015 yılları arasında yayımlanan makalelerin kapsamı ve konuların dağılımı incelendiğinde, 134 $(\% 27,4)$ makalede öğretmenlere öneri en çok geliştirilen ikinci öneri olmuştur. Öğretmenler için geliştirilen önerilerin konu dağılımları incelendiğinde, $53(\% 39,6)$ makalede en çok değinilen konunun oyun eğitimi konusunun olduğu ve en az değinilen konunun ise $1(\% 0,7)$ makalede teknoloji olduğu belirlenmiştir. Sırasıyla 41 (\%30,6) makalede anne baba eğitimi, 15 (\%11,2) makalede öğretmen eğitimi, $9(\% 6,7)$ makalede yaratıclık eğitimi, $5(\% 3,7)$ makalede yetişkin eğitimi, $3(\% 2,2)$ makalede sağlık ve fen eğitimi ve 2 makalede $(\% 1,5)$ diğer ve cinsel eğitim konularına yer verildiği görülmüştür.

1986-2015 yılları arasında yayımlanan makalelerin kapsamı ve konuların dağılımı incelendiğinde, 26 $(\% 5,3)$ makalede çocukla çalışan diğer profesyonellere öneri en çok geliştirilen üçüncü öneri olmuştur. Çocukla çalışan diğer profesyoneller için geliştirilen önerilerin konu dağılımları incelendiğinde, 9 (\%34,6) makalede en çok değinilen konunun öğretmen eğitimi konusunun olduğu ve en az değinilen konunun ise 1 $(\% 3,8)$ makalede diğer, teknoloji ve yetişkin eğitimi olduğu belirlenmiştir. Sırasıyla $7(\% 26,9)$ makalede anne baba eğitimi, $5(\% 19,2)$ makalede oyun eğitimi ve 2 makalede $(\% 7,7)$ cinsel eğitim konularına yer verildiği görülmüştür. Yaşadıkça Eğitim dergisinde erken çocukluk dönemine yönelik yayımlanan makalelerin çocukla çalışan diğer profesyoneller için geliştirilen önerilerde yaratıcılık, fen ve sağlık eğitimi konularına değinilmediği görülmüştür.

1986-2015 yılları arasında yayımlanan makalelerin kapsamı ve konuların dağılımı incelendiğinde, 21 $(\% 4,3)$ makalede politika geliştirici ve yasa koyuculara öneri en çok geliştirilen dördüncü öneri olmuştur. Politika geliştirici ve yasa koyucular için geliştirilen önerilerin konu dağılımları incelendiğinde, $8(\% 38,1)$ makalede en çok değinilen konunun öğretmen eğitimi konusunun olduğu ve en az değinilen konunun ise 1 $(\% 4,8)$ makalede diğer olduğu belirlenmiştir. Sırasıyla 4 (\%19) makalede yetişkin eğitimi, $3(\% 14,3)$ makalede oyun ve anne baba eğitimi ve 2 makalede $(\% 9,5)$ yaratıcılık eğitimi konularına yer verildiği görülmüştür. Yaşadıkça Eğitim dergisinde erken çocukluk dönemine yönelik yayımlanan makalelerin politika geliştirici ve yasa koyucular için geliştirilen önerilerde teknoloji, fen, sağlık ve cinsel eğitim konularına değinilmediği görülmüştür.

1986-2015 yılları arasında yayımlanan makalelerin kapsamı ve konuların dağılımı incelendiğinde, 13 $(\% 2,6)$ makalede medya için öneri en çok geliştirilen beşinci öneri olmuştur. Medya için geliştirilen önerilerin konu dağılımları incelendiğinde, 4 (\%30,8) makalede en çok değinilen konunun anne baba ve öğretmen eğitimi konusunun olduğu ve en az değinilen konunun ise $1(\% 7,7)$ makalede cinsel eğitim olduğu belirlenmiştir. En fazla değinilen ikinci konu $2(\% 15,4)$ makalede oyun ve teknoloji eğitimi olduğu görülmüştür. Yaşadıkça Eğitim dergisinde erken çocukluk dönemine yönelik yayımlanan makalelerin medya için geliştirilen önerilerde teknoloji, fen, diğer, sağlık ve cinsel yetişkin eğitim konularına değinilmediği görülmüştür.

1986-2015 yılları arasında yayımlanan makalelerin kapsamı ve konuların dağılımı incelendiğinde, 12 $(\% 2,4)$ makalede çocuk çevresi için öneri en çok geliştirilen altıncı öneri olmuştur. Çocuk çevresi için geliştirilen önerilerin konu dağılımları incelendiğinde, 6 (\%50) makalede en çok değinilen konunun öğretmen eğitimi konusunun olduğu ve en az değinilen konunun ise $1(\% 8,3)$ makalede cinsel eğitim olduğu belirlenmiş̧ir. En fazla değinilen ikinci konu $5(\% 41,7)$ makalede anne baba eğitimi olarak belirlenmiştir. Yaşadıkça Eğitim dergisinde erken çocukluk dönemine yönelik yayımlanan makalelerin çocuk çevresi için geliştirilen önerilerde teknoloji, yaratıclık, fen, diğer, sağlık, oyun ve yetişkin eğitim konularına değinilmediği görülmüştür.

1986-2015 yılları arasında yayımlanan makalelerin kapsamı ve konuların dağılımı incelendiğinde, 6 (\%1,2) 
makalede araştırmacılar için öneri en az geliştirilen öneri olmuştur. Araştırmacılar için geliştirilen önerilerin konu dağılımları incelendiğinde, 3 (\%50) makalede en çok değinilen konunun oyun eğitimi konusunun olduğu ve en az değinilen konunun ise $1(\% 16,7)$ makalede öğretmen eğitimi olduğu belirlenmiştir. En fazla değinilen ikinci konu 2 (\%33,3) makalede anne baba eğitimi olarak belirlenmiştir. Yaşadıkça Eğitim dergisinde erken çocukluk dönemine yönelik yayımlanan makalelerin araştırmacılar için geliştirilen önerilerde teknoloji, yaratıcılık, fen, cinsel, diğer, sağlık ve yetişkin eğitim konularına değinilmediği görülmüştür.

\section{Sonuç ve Tartışma}

Araştırmadan elde edilen bulgulara göre en çok değinilen konu olan anne baba eğitimi tüm dağılımın $\% 53,3^{\prime}$ ünü oluştururken diğer tüm konular \%46,7'sini oluşturmaktadır. İlgili alan yazın incelendiğinde bu çalışmayı destekler nitelikte sonuca sahip çalışmalarda Özel ve Zelyurt (2016), anne baba eğitimi sayesinde ebeveynlerin çocukları ile iletişimlerinin güçlendiğini, Bolat (2011) ise anne baba eğitiminin hem ebeveyne hem çocuğa önemli derecede katkısı olduğu saptamıştır. Bu araştırmalara ek olarak Özmen (2013), anne baba eğitim programının çocuklardaki davranış sorunları ve anne babalarının depresyon düzeylerine etkisi adlı araştırmada anne baba eğitimi sayesinde çocukların davranış sorunlarında azalma olduğu sonucuna ulaşmıştır. Bu bulgular 1şı̆̆ında Yaşadıkça Eğitim dergisinde anne baba eğitimine önem verilmesi, çocuğun bütünsel gelişimine önem verildiğini göstermektedir.

Anne baba eğitiminden sonra en çok değinilen konu 53 (\%16) makalede öğretmen eğitimi olmuştur. Kefi (2016), erken çocukluk dönemi öğretmenlerinin bilim öğretmede mesleki gelişimleri amacıyla dünyada geliştirilmiş program/projelerin incelenmesi amacıyla yapılan araştırmada öğretmenlerin mesleki gelişimleri için nitelikli kaynakların büyük öneme sahip olduğunu ve bu kaynakların etkili şekilde kullanımı ile öğretmenlerin erken çocukluk dönemindeki çocuklarla daha etkili iletişim kurabildiklerini tespit etmiştir. Bu sonuca göre öğretmen eğitiminin erken çocukluk dönemi için önemli olduğu söylenebilir. Yaşadıkça Eğitim dergisinde yayımlanan erken çocukluk dönemini kapsayan makalelerin daha çok anne baba, öğretmen ve yetişkinlere yönelik olarak yayımlandığı görülmektedir. Çocuğun büyük zamanını ev ve okulda geçirdiği göz önüne alındığında yayımlanan makalelerin anne baba, öğretmen ve yetişkinlere yönelik olması yayın politikasının daha çok yetişkinlere yönelik olduğunu, odak ve kapsamının da çocuğun bakım ve eğitimini üstelenenlerin desteklenmesine yönelik olduğu söylenebilir.

Yayımlanan makalelerin 10'ar yıllık kapsamı ve konuların dağılımı incelendiğinde, en fazla konuya 19861995 yılları arasında değinilmiştir. En fazla konuya sırasıyla 1996-2005 ve 2006-2015 yıllarında yer verildiği görülmüştür. Bu bağlamda Yaşadıkça Eğitim dergisinde zamanla erken çocukluk dönemi eğitimi için yayımlanan makale sayısında azalma olduğu söylenebilir.

Yaşadıkça Eğitim dergisinde yayımlanan erken çocukluk dönemini kapsayan makalelerin farklı on konuya odaklandığı tespit edilmiştir. 1986-1995 yıllarını kapsayan dönemde tüm konulara değinilmiş ve en az değinilen konu $1(\% 0,6)$ makalede yetişkin eğitimi olmuştur. Bu veri, çocuğun bakımı için anne babanın sorumlu tutulduğu ve çevresindeki diğer kişilerin çocuğun bakımında daha az rolünün olduğu yönünde değer göstermektedir. Bu bağlamda dergi dönem toplumuna ayna olacak şekilde yayın hayatına devam etmiştir (Parlak, 2016; Uğur, 2018).

Yayımlanan makalelerin odaklandığı pedagojik alana göre dağılımda çocuk temelli uygulamaya 325 $(\% 97,8)$ makalede odaklanılırken, program temelli uygulamaya $7(\% 2,2)$ makalede odaklanıldığı bulunmuştur. Bu bağlamda Yaşadıkça Eğitim dergisinde yayımlanan makalelerin çocuk odaklı şekilde yayın hayatına devam ettiği söylenebilir. Yaşadıkça Eğitim dergisi tarafından yayımlanan makalelerin çocuk odaklı olarak ebeveynlerin bilgilendirilmesine önem verilmesi, erken çocukluk dönemindeki çocuğun yüksek yararının gözetildiğini gözler önüne sermektedir. Elde edilen bu bulgu, bu konu ile ilgili yapılmış çalışmalarla örtüşmektedir (Aksoy ve Ulutaş, 2014; Kartal, 2005; Öngider, 2013).

Program temelli olarak yayımlanan makaleler anne baba, yetişkin ve öğretmen eğitimi ve diğer konularını kapsamaktadır. Erken çocukluk dönemini kapsayan makalelerde program odaklı $(\% 2,2)$ makale oranı düşük bulunmuştur. Ünver ve Erdamar (2015), erken çocukluk döneminde program geliştirmenin daha çok 
öğretmenlerin işi olduğunu belirtmiştir. Bu bulgu araştırma ile doğru orantılı bulunmuştur.

Yayımlanan makalelerin odaklandığı gelişim alana göre dağılımda $202(\% 35,8)$ makalede sosyal ve duygusal gelişim olmuştur. Bu veriyi sırasıyla $163(\% 28,9)$ makalede bilişsel gelişim, $70(\% 12,4)$ makalede dil gelişimi, 66 (\%11,7) makalede psikomotor gelişim ve 63 (\%11,1) makalede özbakım izlemiştir. Bu bağlamda Yaşadıkça Eğitim dergisinde erken çocukluk dönemindeki çocuklar için en çok sosyal ve duygusal gelişimin önemsendiği sonucuna ulaşılmaktadır. Sosyal ve duygusal gelişimi desteklenen çocuklarda kendi duygularını anlama, başkalarının duygularını anlama, kendini kolayca ifade edebilme vb. sonuçlar elde edilmiştir (Özyürek ve Ceylan, 2014; Saltalı, 2010). Odaklanılan sosyal ve duygusal gelişim alanının en fazla değindiği konu $116(\% 57,4)$ makalede anne baba eğitimi olmuştur. Kandır ve Alpan (2008), tarafından yapılan araştırmada erken çocukluk döneminde çocukların, sosyal ve duygusal gelişimlerinin artması için ebeveynlerin çocuklarını destekleme gerekliliğini belirtilmiştir. Elde edilen veriler, $163(\% 28,9)$ makalede bilişsel gelişime de büyük oranda odaklanıldığını göstermektedir. Bu bağlamda Yaşadıkça Eğitim dergisinin incelenen makalelerinde erken çocukluk döneminde çocukların sosyal ve duygusal gelişimleri kadar bilişsel gelişimlerinin de önemli olduğu verisine ulaşılabilmektedir. Bilişsel gelişim içerisinde en çok değinilen konu 75 (\%46) makalede anne baba eğitimi olmuştur. Dolayısıyla bilişsel gelişim için anne baba faktörünün erken çocukluk döneminde büyük öneme sahip olduğu anlaşılmaktadır. Kol (2011), tarafından yapılan araştırmada ailenin bilinç düzeyi ve erken çocukluk dönemindeki çocuğa sağladığ gelişimi arasında doğru orantı bulunmuştur.

Geliştirilen öneriler incelendiğinde sonucunda en fazla öneri $276(\% 56,5)$ makalede anne babalara yönelik olmuştur. Anne babaların çocukları ile sağlıklı iletişim kurabilmeleri, onlarla oyun oynayabilmeleri, çocukları için zengin uyarıcılı ortamlar hazırlayabilmeleri ve gelişimlerini destekleyebilmeleri konusunda uzman desteğine ihtiyaçları bulunmaktadır. Çocukların becerilerini geliştirmenin en etkili yolu anne baba eğitim programlarıdır (Kelly, Morisset, Barnard, Hammond ve Booth, 1996; Kılınç ve Aral, 2015). Bu bağlamda anne babanın bilinçlilik düzeyi ile çocuğun hayata karşı tutumu ve olumlu yönde hazırlanışı doğru orantılıdır. Dolayısıyla araştırma kapsamında incelenen Yaşadıkça Eğitim dergisinde yayımlanan makalelerin büyük oranda anne babalara $(\% 56,5)$ öneri veriyor olması erken çocukluk dönemindeki gereksinime göre yayın yaptığının göstergesidir. Geliştirilen öneriler incelendiğinde gündem olan konular içerisinde $134(\% 27,4)$ makalede öğretmene öneriler ikinci sırada bulunmaktadır. Erken çocukluk döneminde anne babadan sonra en fazla zaman geçirilen kişi olan öğretmenin çocuğun gelişimindeki yeri yadsınamaz. Dolayısıyla öğretmene verilen öneriler doğrultusunda öğretmenin de kendisini geliştirmesi çocuğun yararına olacaktır. Yapılan araştırmalar da bu bulguyu destekler niteliktedir (Akgün, Yarar ve Dinçer, 2011; Çetintaş ve Yazıc1, 2016; Ünal ve Akman, 2006; Yalçın ve diğerleri, 2017). Öğretmenlere öneriler içerikli makalelerin, en fazla odaklandığı konu $53(\% 39,6)$ makalede oyun eğitimi olmuştur.

\section{Öneriler}

Bu bölümde Yaşadıkça Eğitim dergisi bulgularına paralel olarak popüler eğitim dergisi olan dergilere şu öneriler geliştirilmiştir;

1. Erken çocukluk eğitiminde meydana gelen değişimlerin izlenmesi, ortaya çıkan yeni uygulamaların tanıtımı ve çocuk ve ailenin ihtiyaçları göz önünde bulundurularak popüler eğitim dergileri yayın politikalarını belirleyebilir.

2. Popüler eğitim dergilerinin yayın politikalarının merkezinde aynı zamanda bilimsel çalışmaları takip ederek alana yön verilebilir.

3. Yurtiçi ve yurtdışı kaynaklı uzun süreli yayın yapmış ve hala yayın yapmaya devam eden dergiler üzerinden karşılaştırmalı araştırmalar yapılabilir.

4. Araştırma sonucunda elde edilen bulgular doğrultusunda daha az yer verilmiş konularda araştırmacılar teşvik edilebilir, daha az yayınlanan konularda özel sayılar çıkarılabilir.

5. Bu araştırmaya 1986-2015 yılları arasında yayın yapmış olan Yaşadıkça Eğitim dergisi dahil edilmiştir. İleride yapılacak araştırmalar için dergi sayısı artıılarak alınyazına genellenebilir sonuçlar elde edilebilir. 


\section{Yazar(lar)1n Beyanı}

Araştırmacıların katkı oranı beyanı: Makalenin birinci yazarı verilerin toplanması, verilerin analizi, bulguların sunumuna katkıda bulunmuştur. Ikkinci yazar araştırmanın tasarımı, araştırmanın yeniden gözden geçirilerek düzenlenmesine, analiz ve yorumların yapılmasına katkı sunmuştur.

Çatışma beyanı: Herhangi bir çıkar çatışması bulunmamaktadır.

Destek ve teşekkür: Bu araştırmanın gerçekleştirilmesi için herhangi kişi ya da kurumlardan fon desteği sağlanmamiştır.

\section{Editöryal Beyan}

Araştırmanın hakemlik süreci misafir editör Dr. Erhan Alabay tarafından yürütülmüş̧ür. Değerlendirme sonrası karar Dr. Erhan Alabay tarafından kaydedilmiştir. Misafir editörün makalenin yazarları ile bir çıkar çatışması bulunmamaktadır.

\section{Kaynaklar}

Akgün, E., Yarar, M. ve Dinçer, Ç. (2011). Okul öncesi öğretmenlerin sınıf içi etkinliklerde kullandıkları sınıf yönetimi stratejilerinin incelenmesi. Pegem Ĕ̆itim ve Öğretim Dergisi, 1(3), 1-9.

Aksoy, A. B. ve Ulutaş, I. (2014). Child centered attitudes of mothers and maternal self-perception. International Academic Conference on Social Sciences and Humanities in Prague. Prague.

Aksoy, P. ve Baran, G. (2018). Dil Gelişimi. A. Köksal Akyol (Ed.), Erken çocukluk döneminde gelişim II 36-72 Ay (s. 144-171) içinde. Ankara: Anı Yayıncılık.

Alıcı, C. E. (2018). Okul öncesi dönemde tersine kaynaştırma gruplarında yer alan cerebral palsy'li çocukların ince motor becerilerinin oyunla desteklenmesi (Yayımlanmamış yüksek lisans tezi). Gazi Üniversitesi, Eğitim Bilimleri Enstitüsü, Ankara.

Arat, M. (2008). Çalı̧̧ma yaşamında bireysel temel yetkinlikler ve kazanılmasında okul öncesi dönemde anne baba yetiştirmesinin önemi (Yayımlanmamış doktora tezi). Dokuz Eylül Üniversitesi, Sosyal Bilimler Enstitüsü, İzmir.

Bardak, M. (2010). I. Meşrutiyet döneminde okul öncesi eğitim (1908-1918) (Yayımlanmamış yüksek lisans tezi). Firat Üniveristesi, Sosyal Bilimleri Enstitüsü, Elazığ.

Bolat, E. Y. (2011). Anne baba eğitiminin beş altı yaş çocuğa sahip anne babaların çocuk yetiştirme tutum ve davranışlarına etkisinin incelenmesi (Yayımlanmamış doktora tezi). Ankara Üniversitesi, Fen Bilimleri Enstitüsü, Ankara.

Cömert, D. ve Güleç, H. (2004). Okul öncesi eğitim kurumlarında aile katılımının önemi: Öğretmen-aile-çocuk ve kurum. Sosyal Bilimler Dergisi, 6(1), 131-145.

Çağlayan, Ç. (2015). Çocuk ve Çevre. Türkiye Klinikleri, 1(2), 32-38.

Çelik, İ. (2018). Noam chomsky ve psiko-linguistik dil gelişim kuramı. International Periodical for the Languages, Literature and History of Turkish or Turkic, 12(28), 193-208.

Çelik, M. ve Gündoğdu, K. (2007). Türkiye'de okul öncesi eğitimin tarihsel gelişimi. Kazım Karabekir Eğitim Fakültesi Dergisi, 16, 172-190.

Çetintaş, B. G. ve Yazıcı, Z. (2016). Erken çocukluk döneminde anaokulu ve anasınıflarında iki dilli eğitim uygulamaları ve deneyimleri üzerine öğretmen görüşleri. Mediterranean Journal of Humanities, 6(2), 173187.

Demir, Ü. (2016). Sosyal medya kullanımı ve aile iletişimi: Çanakkale'de lise öğrencileri üzerinde bir araştırma. Selçuk Üniversitesi Dergisi, 9(2), 27-50. 
Deniz, Ü. ve Kesicioğlu, O. S. (2012). Okul öncesi öğretmen adaylarının kişilik özelliklerinin bazı değişkenlerle ilişkisinin incelenmesi. Ahi Evran Üniversitesi Kırşehir Eğitim Fakültesi Dergisi (KEFAD), 13(2), 1-13.

Didin, E. ve Köksal Akyol, A. (2018). Bilişsel gelişim. A. Köksal Akyol (Ed.), Erken çocukluk döneminde gelişim (s. 242-264) içinde. Ankara: Anı Yayıncılık.

Kandır, A. ve Alpan, Y. (2008). Okul öncesi dönemde sosyal-duygusal gelişime anne-baba davranışlarının etkisi. Aile ve Toplum Ĕ̆itim Kültür ve Araştırma Dergisi, 4(14), 33-38.

Kartal, H. (2005). Erken çocukluk eğitim programlarından Anne-Çocuk Eğitim Programı'nın 6 yaş grubundaki çocukların bilişsel gelişimine etkisi (Yayımlanmamış doktora tezi). Uludağ Üniversitesi, Sosyal Bilimler Enstitüsü, Ankara.

Kaya, A. ve Efe, E. (2016). Pre-school period of development. Annals of Nursing and Practice, 1(2), 1044.

Kayhan, E., Bağcl, Ö. A. ve Erişen, Y. (2019). Sıbyan mektepleri ile okul öncesi öğretim programlarında değerler eğitimi. İlköğretim Online, 18(3), 990-1013.

Kaynak, M. (2016). Motor gelişim. E. Arslan (Ed.), Erken çocukluk döneminde gelişim (s. 67-84) içinde. Ankara: Eğiten Kitap Yayıncılık.

Kefi, S. (2016). Erken çocukluk öğretmenlerinin bilim öğretmede mesleki gelişimleri amacıyla dünyada geliştirilmiş program/projelerin incelenmesi. Eğitim ve Öğretim Araştırmaları Dergisi, 5(39), 343-360.

Kelly, J. F., Morisset, C. E., Barnard, K. E., Hammond, M. A. ve Booth, C. L. (1996). The influence of early mother- child interaction on preschool cognitive/linguistic outcomes in a high-social-risk group. Infant Mental Health Journal, 17(4), 310-321.

Kerigan, B. (2018). Okul öncesi dönem çocuklarına etkileşimli okuma yöntemiyle sosyal becerilerin kazandırılması (Yayımlanmamış yüksek lisans tezi). Bahçeşehir Üniversitesi, Eğitim Bilimleri Enstitüsü, İstanbul.

Kılınç, F. E. ve Aral, N. (2015). Erken müdahale için bir model: Anne çocuk etkileşim programı. Hacettepe Üniversitesi Sağlık Bilimleri Fakültesi Dergisi, 1(2), 63-76.

Koçyiğit, S. (2007). Farklı ülkelerde okul öncesi eğitim kurumlarının gelişimi (Yayımlanmamış yüksek lisans tezi). Atatürk Üniversitesi, Sosyal Bilimler Enstitüsü, Erzurum.

Kol, S. (2011). Erken çocuklukta bilişsel gelişim ve dil gelişimi. Sakarya Üniversitesi Eğitim Fakültesi Dergisi, 21, $1-21$.

Küçükturan, G. ve Keleş, S. (2018). Sosyal duygusal gelişim. A. Köksal Akyol (Ed.), Erken çocukluk döneminde gelişim II (s. 199-243) içinde. Ankara: Anı Yayıncılık.

Miles, M, B. ve Huberman, A. M. (1994). Qualitative data analysis: An expanded sourcebook (2. bs). Thousand Oaks, CA: Sage.

Milli Eğitim Bakanlığı. (2013). Okul öncesi eğitimi programı. Ankara: Milli Eğitim Bakanlığı Temel Eğitim Genel Müdürlüğü.

Milli Eğitim Bakanlığı. (2019). Milli Eğitim İstatistikleri Örgün Eğitim. 6 Haziran tarihinde sgb.meb.gov.tr: https://sgb.meb.gov.tr/meb_iys_dosyalar/2018_09/06123056_meb_istatistikleri_orgun_egitim_2017_2018. pdf adresinden erişildi.

Öngider, N. (2013). Anne-baba ile okul öncesi çocuk arasındaki ilişki. Psikiyatride Güncel Yaklaşımlar, 5(4), 420440.

Özel, E. ve Zelyurt, H. (2016). Anne baba eğitiminin aile çocuk ilişkilerine etkisi. Sosyal Politika Çalışmaları Dergisi, 36, 9-34.

Özgün, Ö. (2015). Ebeveynlikle ilgili kuramlar ve araştırmalar. Z. F. Temel (Ed.), Aile eğitimi ve erken çocukluk eğitiminde aile katılım çalışmaları (s. 72-109) içinde. Ankara: Anı Yayıncılık. 
Özmen, S. K. (2013). Anne-baba eğitimi programının çocuklardaki davranış sorunları ve anne-babaların depresyon düzeylerine etkisi. Eğitim ve Bilim, 38(167), 98-113.

Özyürek, A. ve Ceylan, Ş. (2014). Okul öncesi çocuklarda sosyal becerilerin desteklenmesi konusunda öğretmen ve veli görüşlerinin belirlenmesi. Pamukkale Üniversitesi Eğitim Fakültesi Dergisi, 35, 99-114.

Özyürek, A., Çetin, A., Yıldırım, R., Evirgen, N. ve Ergün, Ş. (2016). Farklı kültürlerde aile çocuk etkileşimlerinin öğretmen bakış açısına göre incelenmesi.Uluslararası Sosyal Araştırmalar Dergisi, 9(43), 1477-1484.

Parlak, N. K. (2016). İş-Yaşam dengesi açısından çocuk bakım hizmetleri. Uluslararası Hakemli Sosyal Bilimler E-Dergisi, 58, 159-184.

Saltalı, N. D. (2010). Duygu eğitiminin okul öncesi dönem çocuklarının duygusal becerilerine etkisi (Yayınlanmamış doktora tezi). Selçuk Üniversitesi, Sosyal Bilimler Enstitüsü, Konya.

Seggie, F. N. ve Bayburt, Y. (2017). Nitel araştırma yöntemlerine giriş. F. N. Seggie ve Y. Bayburt (Ed.), Nitel araştırma yöntem, teknil, analiz ve yaklaşımları (s. 11-22) içinde. Ankara: Anı Yayıncılık.

Sıbyan Mektebi Tarihçesi. (2019, Haziran). www.siyasalvakfi.org: Erişim adresi: http://www.siyasalvakfi.org/hakkimizda/tarihce/sibyan-mektebi-tarihcesi-3.html

Sönmez, İ. (2019). Okul öncesi dönem çocuklarının erken öğrenme alanlarındaki davranış ve becerilerinin incelenmesi (Yayınlanmamış yüksek lisans tezi). Trakya Üniversitesi, Sosyal Bilimleri Enstitüsü, Edirne.

Sözbilir, M., Kutu, H. ve Yaşar, D. (2012). Science education research in Turkey: A content analysis of selected features of published papers. D. J. Dillon (Ed.), The world of science education: Handbook of research in Europe (s. 341-374) içinde. Rotterdam: Sense Publishers.

Şimşek, H. ve Şimşek, S. (2015). Ailenin dönüşümü ve aile sorumluluğu bağlaminda etüt merkezlerini yeniden düşünmek. Kastamonu Eğitim Dergisi, 23(1), 365-384.

Toran, M. (2012). Çocukluğun ve erken çocukluk eğitiminin tarihi ve kuramsal temelleri. N. Avcı ve M. Toran (Ed.), Okul öncesi eğitimine giriş (s. 1-19) içinde. Ankara: Eğiten Yayınları.

Uğur, S. B. (2018). Geçmişten günümüze şekillenen çocukluk algısı ve çocuk yetiştirme pratikleri. Süleyman Demirel Üniversitesi Fen Edebiyat Fakültesi Sosyal Bilimler Dergisi, (45), 227-247.

Ulutaş, A., Demir, E. ve Yayan, E. H. (2017). Motor gelişim eğitim programının 5-6 yaş çocukların kaba ve ince motor becerilerine etkisinin incelenmesi. Abant İzzet Baysal Üniversitesi Ĕ̆itim Fakültesi Dergisi, 17(3), 15231538.

Ünal, M. ve Akman, B. (2006). Okul öncesi öğretmenlerinin fen eğitimine karşı gösterdikleri tutumlar. Hacettepe Üniversitesi Ĕ̆itim Fakültesi Dergisi, 30, 251-257.

Ünver, G. ve Erdamar, G. (2015). Türkiye'de Erken çocukluk dönemi öğretmenlerinin eğitim programı geliştirme sürecine katkıları. Ahi Evran Üniversitesi Kırşehir Eğitim Fakültesi Dergisi (KEFAD), 16(1), 215-234.

Yalçın, F. A., Yalçın, M. ve Macun, B. (2017). Okul öncesi öğretmenlerinin okul öncesi eğitimde öğretmen cinsiyeti ile ilgili görüşleri. Bayburt Eğitim Fakültesi Dergisi, 12(24), 693-710.

Yıldırım, A. ve Şimşek, H. (2016). Sosyal bilimlerde nitel araştırma yöntemleri. Ankara: Seçkin Yayıncllık.

Yıldız, A. K. (2017). Okul öncesi dönem çocuğunun eğitim ve gelişiminde kitabın rolü ve bu süreçte anaokulu kütüphanelerinin gerekliliği. International Journal of Social Sciences and Education Research, 3(3), 792-802. 


\section{EXTENDED ABSTRACT}

\section{Introduction}

The aim of the study was to examine early childhood period having a critical importance on the development of a child in terms of family, environment and school components. Considering the historical development of early childhood period, it was found that education has gained importance since the ancient times and early childhood period showed a development in different periods and ways in Turkey and in the world. Therefore, examining early childhood period education in the historical context is important. It is considered that the present study will contribute to the current literature in terms of determining the topic subjects by examining the history of early childhood period in Turkey. Moreover, determining the topic subjects regarding early childhood period education may show which subjects are significant in early childhood education. In line with these facts, the aim of the study was to examine the topic studies on early childhood period. Thus, the answers for the following questions were sought:

1- What is the distribution of topic studies on early childhood period?

2- What are the topic studies based on 10-year evaluations?

3- Which pedagogical practices are focused on the topic studies in early childhood period?

4- Which areas of development are focused on the topic studies in early childhood period?

5- What are the recommendations made by the topic studies in early childhood period?

\section{Method}

This study was conducted in a qualitative design. The researchers decided that the qualitative study method was optimal for this study aiming to examine and interpret the topic subjects in early childhood. The study used document analysis since to the purpose was to examine all parts of the "Journal of Education for Life", a popular education journal published between 1986 and 2015. Document review included the analysis of written materials having information on the fact or facts to be examined (Yıldırım and Şimşek, 2016). The historical method (documentary history) enabling the examination of events or facts in the past or the historical relation of a problem was used in the study. The historical method is the examination and evaluation of the events in the past with a questioning perspective to find the truth about them (Kayhan, Bağ $\mathrm{Cl}$ and Erişen, 2019).

The Journal of Education for Life was a popular education journal between 1986 and 2015, and had the characteristic of being an academic journal as of 2015. The popular issues of the Journal of Education for Life were examined in the study. Thus, the data of the study were the subjects about "Early Childhood Period" among the 125 issues of the "Journal of Education for Life" published between 1986 and 2015. All issues were obtained from the archives of the Journal of Education for Life.

The opinions of three faculty members, experts in this field about the "Article Classification Form" developed by Sözbilir, Kutu and Yaşar (2012) and revised by the researchers to ensure its content validity was obtained. The form was readjusted based on expert opinions. The researcher coded the randomly selected three issues of the journal on the form. The coded journals were coded by a separate researcher at a different time to test the reliability of the form. The study used descriptive analysis to examine the article identity, subject, areas of development, study method, data collection instruments, sampling and data analysis techniques sections of the Article Classification Form. Each article was classified according to the predefined categories in the form.

\section{Results}

The results of the study showed that the parents' education was a highly discussed subject at the rate of $53.3 \%$ while all other subjects formed the remaining $46.7 \%$. Teacher education took the second place following the parents' education and it was stated in 53 articles (16\%). Considering the distribution of 10-year scope and subjects in the articles, the number of subjects discussed in the articles was the highest between 1986 and 1995. The highest number of subjects was between 1996 and 2005, and 2006 and 2015, respectively. It was found that 
the articles on early childhood period which were published in the The Journal of Education for Life focused on 10 different subjects. The articles published between 1986 and 1995 addressed all subjects and adult education was only stated in one article $(0.6 \%)$. The distribution of the pedagogical fields on which the articles focused showed that 325 articles $(97.8 \%)$ focused on child-based practices while 7 articles $(2.2 \%)$ focused on program-based practices. The articles which were published as program-based included parent, adult and teacher training and other subjects. The rate of program-based articles $(2.2 \%)$ was found to be low among the articles on early childhood period. The distribution of the areas of development in the articles showed that 202 articles (35.8\%) were about social and emotional development. Among the articles, $163(28.9 \%)$ were on cognitive development, $70(12.4 \%)$ were on language development, $66(11.7 \%)$ were on psychomotor development and $63(11.1 \%)$ were on self-care. The subject that was discussed the most in the field of social and emotional development was parents' education in 116 articles (57.4\%). Considering the recommendations made in the articles, most of the recommendations were for parents in 276 articles (56.5\%).

\section{Conclusion}

In conclusion, it was found that the early childhood-related subjects addressed on the popular issues of the Journal of Education for Life published between 1986 and 2015 varied. The subjects discussed in the articles were generally about parents and the recommendations were on child-based practices. It has been found that the Journal of Education for Life has shed light on today's world, and the subjects in the articles are still discussed. 